Marija Logarušić*

Irena Raguž Krištic *
JEL Classification C23, E24, O52 Prethodno priopćenje

https://doi.org/10.32910/ep.70.4.1

\title{
ODREDNICE NEZAPOSLENOSTI U EUROPSKOJ UNIJI
}

Nezaposlenost kao jedan od važnih ekonomskih problema zaokuplja pažnju brojnih istraživača, posebice od globalne financijske krize koja je uzrokovala visoke i trajne stope nezaposlenosti u Europskoj uniji (EU). Cilj ovoga rada je utvrditi značajne makroekonomske odrednice nezaposlenosti u EU. U tu svrhu u radu je provedena dinamička panel analiza za svih 28 članica EU u razdoblju od 1995. do 2016. godine. Sveobuhvatnošću provedene analize utemeljene na ekonomskoj teoriji, koja uključuje svih 28 zemalja članica EU kroz do sada najduži promatrani period promatranja, ispitivanje homogenosti odrednica unutar EU te odrednice nezaposlenosti mladih, ovim radom se doprinosi postojećoj literaturi. Analizom je potvrđena značajnost jaza proizvodnje, investicija, realne dugoročne kamatne stope, inflacije i nezaposlenosti u prethodnom razdoblju kao odrednica nezaposlenosti u čitavoj $E U$, pri čemu su samo realna kamatna stopa $i$ nezaposlenost iz prethodnog razdoblja robusne u svim modelima. Odrednice nezaposlenosti u starim i novim zemljama članicama pokazale su se relativno homogenima. Stopa rasta proizvodnje ima značajan negativan učinak samo na nezaposlenost mladih. Veza jaza nezaposlenosti i jaza proizvodnje dodatno je istražena statičkom

* M. Logarušić, mag. oec., asistentica, Sveučilište u Zagrebu, Ekonomski fakultet (e-mail: mlogarusic@efzg.hr).

** Dr. sc. I. Raguž Krištić, docentica, Sveučilište u Zagrebu, Ekonomski fakultet (e-mail: iraguzkristic@efzg.hr).

Ovaj rad ni na koji način ne predstavlja stajalište EFZG-a na temu „Odrednice nezaposlenosti u Europskoj uniji“" te isključivo prezentira osobne stavove autorica Marije Logarušić i Irene Raguž Krištić.

Rad je djelomično financirala Hrvatska zaklada za znanost, pod projektnim brojem 6785.

Rad je primljen u uredništvo 16.04.2018. godine, a prihvaćen je za objavu 13.02.2019. godine. 
panel analizom te se zaključuje kako je Okunov zakon u EU valjan, odnosno postoji negativna veza između jaza nezaposlenosti i jaza proizvodnje.

Ključne riječi: nezaposlenost, Okunov zakon, dinamički panel

\section{Uvod ${ }^{1}$}

Nezaposlenost ima iznimnu makroekonomsku važnost iz dva razloga. Prvo, stopa nezaposlenosti govori djeluje li gospodarstvo iznad ili ispod svoje normalne razine aktivnosti. Odnosno, godišnje promjene stope nezaposlenosti su vrlo usko povezane uz razdoblja recesija i ekspanzija. Drugo, nezaposlenost ima ozbiljne društvene posljedice. Opća stopa nezaposlenosti utječe na nadnice, te time utječe i na blagostanje svakog pojedinog radnika (Blanchard, 2005). Članstvo u Europskoj uniji (EU) je zemljama članicama trebalo osigurati savršenu mobilnost radne snage, integraciju tržišta rada, i posljedično niže stope nezaposlenosti. Međutim, posljednja globalna financijska kriza razotkrila je temeljne probleme u funkcioniranju Europske unije (Krugman, 2012), i to prvenstveno kroz nedovoljnu integriranost tržišta rada (ECB, 2012), i posljedično probleme visoke strukturne nezaposlenosti (ECB, 2016).

Cilj ovog rada je stoga analizirati makroekonomske odrednice nezaposlenosti u EU te dublje istražiti vezu između nezaposlenosti i proizvodnje koja se definira Okunovim zakonom. U radu se traži odgovor na pitanje kakvu ulogu imaju makroekonomske varijable pri određivanju nezaposlenosti u EU. Varijable su odabrane na temelju post-Kejnezijanske ekonomske teorije (Stockhammer, Guschanski i Köhler, 2014), te na temelju ranije provedenih istraživanja koja sugeriraju kako je potražnja dominantna u objašnjavanju nezaposlenosti, i u kratkom i u srednjem roku. Varijable koje testiramo su stopa rasta bruto domaćeg proizvoda (BDP-a), jaz proizvodnje, inflacija, realna dugoročna kamatna stopa, te realne investicije.

U radu se dinamičkom panel analizom testiraju odrednice nezaposlenosti na strani potražnje na uzorku svih 28 zemalja članica EU u razdoblju od 1995. do 2016. godine, te se procjenjuje model s fiksnim efektima za prikaz Okunovog zakona. Analizirani vremenski period obuhvaća najduže do sada promatrano razdoblje u odnosu na postojeću literaturu, s ciljem analize odrednica nezaposlenosti u novoj Europi, nastaloj po završetku socijalizma i formiranja novih tržišnih gospodarstava. Pritom se nakon početne analize odrednica nezaposlenosti na razini čita-

1 Ovaj rad je temeljen na istraživanju provedenom za završni rad pod nazivom „Determinante nezaposlenosti u EU“ pristupnice Marije Logarušić, mag.oec. pod mentorstvom doc.dr.sc. Irene Raguž Krištić. 
ve EU zemlje dodatno grupiraju u dvije skupine - na stare i nove zemlje članice, pri čemu se kao kriterij za nove zemlje članice uzima proširenje Europske unije 2004. godine. Na taj način se ispituje u kojoj mjeri je EU homogena po pitanju nezaposlenosti i njezinih odrednica te se istovremeno ispituje i robusnost osnovnih rezultata analize. Kao dodatna analiza robusnosti u radu se provodi i analiza odrednica stope nezaposlenosti mladih, kao posebno interesantne skupine stanovništva u EU suočene s problemom visoke nezaposlenosti. Sveobuhvatnost provedene analize utemeljene na ekonomskoj teoriji, koja uključuje svih 28 zemalja članica EU, do sada najduži analizirani period promatranja, ispitivanje homogenosti odrednica nezaposlenosti unutar EU te odrednice nezaposlenosti mladih, stoga predstavlja doprinos ovog rada postojećoj literaturi koja se spomenutim pitanjima do sada bavila parcijalno.

U nastavku rada se za početak pruža pregled postojeće literature, nakon čega se detaljno objašnjava korišteni empirijski model. Slijedi obrazloženje korištenih podataka i metodologije te empirijska analiza. U konačnici se sumiraju najvažniji zaključci rada.

\section{Pregled literature}

Nezaposlenost je jedna od tri glavne makroekonomske varijable uz BDP i stopu inflacije, te nije neobično da kao takva zaokuplja pažnju brojnih istraživača. Nezaposlenost se smatra i jednim od najvećih problema društva i pojedinca (Kljaić, 2001). U postojećoj literaturi, teorijskoj i empirijskoj, detaljno su analizirane odrednice nezaposlenosti. Općenito, prema neoklasičnoj teoriji nezaposlenost je uzrokovana faktorima na strani ponude (Bierens i Broersma, 1993). Nova Keynezijanska NAIRU (eng. non-accelerating inflation rate of unemployment) teorija sugerira kako je nezaposlenost $\mathrm{u}$ kratkom roku uzrokovana faktorima na strani potražnje, dok je u srednjem roku određuju institucije tržišta rada. Prema post Keynezijanskoj teoriji, tržište rada je pod dominantnim utjecajem potražnje i u kratkom i u srednjem roku (Stockhammer i sur., 2014). Neke od najčešćih odrednica analiziranih u literaturi su makroekonomske varijable poput stope rasta BDP-a, jaza proizvodnje, investicija, inflacije i realnih kamatnih stopa, ali i varijable poput realnih plaća, produktivnosti radnika, aktivnih politika na tržištu rada, naknada za nezaposlene, sindikata i sl.

Veza između rasta domaćeg proizvoda i promjene stope nezaposlenosti u literaturi je dobro poznata kao Okunov zakon (Okun, 1962). Stopa rasta domaćeg proizvoda iznad normalne stope očekuje se da će dovesti do smanjenja stope nezaposlenosti, i obrnuto, pri čemu je normalna stopa rasta BDP-a održiva 
stopa rasta BDP-a koja gospodarstvo zadržava u fazi ekspanzije. Dakle, očekivani odnos između stope rasta domaćeg proizvoda i promjene nezaposlenosti je negativan. Ukoliko promotrimo vezu između jaza proizvodnje i nezaposlenosti, možemo pretpostaviti negativnu vezu, odnosno kada je stvarna proizvodnja veća od potencijalne, tj. kada je jaz proizvodnje pozitivan, nezaposlenost će biti manja. Potencijalna proizvodnja pritom predstavlja razinu proizvodnje koju gospodarstvo može proizvesti uz stabilnu stopu inflacije (OECD, 2017).

Utjecaj inflacije kao odrednice nezaposlenosti analizira se pomoću relacije agregatne potražnje, pri čemu inflacija smanjuje realnu ponudu novca, povećava kamatne stope i negativno djeluje na proizvodnu aktivnost te u kratkom roku povećava stopu nezaposlenosti. Alternativno, ukoliko središnja banka cilja određenu stopu inflacije, njezina će reakcija na porast inflacije činiti relaciju agregatne potražnje negativnom i opet dovoditi do povećanja stope nezaposlenosti. Srednjoročni učinci inflacije na nezaposlenost su također pozitivni. Ukoliko se izvor inflacije nalazi na strani ponude, tj. proizlazi iz uvjeta na tržištu rada, srednjoročna stopa nezaposlenosti će uslijed povećanja inflacije također rasti (Blanchard, 2005). Ukoliko je izvor povećanja stope inflacije na potražnoj strani, nova Keynezijanska teorija tvrdi kako će srednjoročna (normalna) stopa nezaposlenosti ostati nepromijenjena. Međutim, post Keynezijanska teorija ističe kako bilo koja kratkoročna razina realnih nadnica može postati prihvaćena kao „normalna“ ukoliko dovoljno dugo potraje, budući da radnici svoje nadnice najčešće uspoređuju s nadnicama ostalih radnika ili svojim ranijim nadnicama (Stockhammer i sur., 2014). Time i inflacija potaknuta potražnjom vrlo lako može imati srednjoročne pozitivne učinke, što uostalom potvrđuju i brojne studije o histerezi odnosno perzistentnosti nezaposlenosti (Raguž Krištić, Rogić Dumančić i Arčabić, 2018).

Nadalje, teorijska povezanost kamatne stope i stope nezaposlenosti je pozitivna. Kamatna stopa ima nepovoljan utjecaj na nezaposlenost, odnosno uz veću kamatnu stopu, skuplje kreditiranje i privlačniju štednju, te posljedično smanjenje agregatne potražnje i stope rasta gospodarstva, nezaposlenost će također biti veća. Iz navedenog se iščitava i negativna veza između investicija i stope nezaposlenosti, preko povećanja proizvodnje (Blanchard, 2005). Investicije, međutim, imaju utjecaj na nezaposlenost i preko utjecaja na marže poduzeća i njihovu relaciju određivanja cijena, odnosno preko relacije agregatne ponude (Stockhammer i sur., 2014).

Pitanje koje se postavlja u ovom radu je u kojoj mjeri je navedenim odrednicama moguće objasniti kretanje nezaposlenosti u Europskoj uniji kako bi se omogućilo bolje razumijevanje njezinog problema visoke nezaposlenosti. U nastavku se pruža prikaz empirijskih radova koji su već istraživali odrednice nezaposlenosti, s posebnim naglaskom na zemlje EU i zemlje slične razine razvijenosti. Pregled je organiziran prema različitim metodološkim pristupima korištenima u postojećoj literaturi - analize vremenskih serija i panel analize. 
Između ostalih, analizom vremenskih serija koriste se Bierens i Broersma (1993) koji na temelju mjesečnih podataka od 1960. do 1987. za Sjedinjene Američke Države (SAD), Kanadu, Japan, Njemačku, Ujedinjeno Kraljevstvo, Francusku i Nizozemsku zaključuju da kamatna stopa i stopa rasta industrijske proizvodnje značajno utječu na nezaposlenost u svim promatranim zemljama. Indeks nadnica, pak, osim za Nizozemsku, ne pokazuje značajan utjecaj na nezaposlenost u njihovom istraživanju. Li (2006) analizira realni BDP, realne investicije, realnu potrošnju, stopu inflacije, realnu kamatnu stopu i jaz proizvodnje kao odrednice nezaposlenosti u SAD-u na podacima od 1948. do 2005. godine, te zaključuje da su realni BDP, realne investicije i realna kamatna stopa glavne odrednice nezaposlenosti u SAD-u u promatranom razdoblju. Obadić (2006) analizom Češke, Hrvatske, Poljske, Slovačke i Slovenije utvrđuje neslaganje ponude i potražnje (eng. mismatch) na tržištu rada kao značajan faktor u smanjivanju zaposlenosti u promatranim zemljama. Tercek i Simmons (2014) analiziraju vremenske serije nezaposlenosti od 1990. do 2012. za Francusku, Njemačku, Španjolsku i SAD te zaključuju da postoji negativna veza stope inflacije i stope nezaposlenosti, te pozitivna veza izdataka za nezaposlene i stope nezaposlenosti. Brojne varijable tržišta rada pokazale su se nesignifikantnima. U kontekstu Okunovog zakona, Karfakis, Katrakilidis i Tsanana (2014) potvrđuju da realna proizvodnja ima snažan utjecaj na nezaposlenost u Grčkoj od 2000. do 2012. te zaključuju kako je Okunov omjer 3:1, odnosno da 1 posto povećanja nezaposlenosti je povezano s 3 posto smanjenja realne proizvodnje. Quade (2003) jednostavnom regresijskom vezom nezaposlenosti i proizvodnje također dobiva snažnu negativnu vezu na uzorku saveznih država SAD-a uz kvartalne podatke od 1977. do 2001. Autor dolazi do zaključka kako je Okunov koeficijent promatranog uzorka jednak -0,10. Ball, Leigh i Loungani (2013) promatraju vezu stope nezaposlenosti i stope rasta proizvodnje u SAD-u za razdoblje od 1948. do 2011. godine na kvartalnim i godišnjim podacima, te u dvadeset razvijenih ekonomija od 1980. do 2011. godine uz godišnje podatke. Koriste dva pristupa procjeni Okunovog zakona, regresijsku jednadžbu u razinama uključujući varijable jaz proizvodnje i jaz nezaposlenosti, te u diferencijama varijabli proizvodnje i nezaposlenosti, preferirajući metodu jaza, te zaključuju da je za SAD Okunov koeficijent $-0,45$, dok je u ostalim promatranim zemljama Okunov koeficijent također negativan, od -0,14 u Austriji do -0,85 u Španjolskoj.

Osim analiza vremenskih serija, u postojećoj literaturi je korištena i panel analiza odrednica nezaposlenosti. Jednu takvu opsežniju analizu odrednica nezaposlenosti provode Bacarro i Rei (2007) koji koriste dinamički model kako bi analizirali institucionalne i makroekonomske odrednice nezaposlenosti. Na temelju podataka 18 OECD zemalja u razdoblju od 1960. do 1998. autori zaključuju kako institucionalne odrednice nisu značajne u određivanju nezaposlenosti, već su to realne kamatne stope i nezavisne središnje banke. Adascalitei i Morano (2015) dinamičkom panel analizom pronalaze statistički značajne učinke jaza proizvod- 
nje, otvorenosti tržišta i inflacije te stupnja deregulacije tržišta rada na stope nezaposlenosti razvijenih zemalja od 2008. do 2014., pri čemu se pokazalo kako deregulacija povećava stope nezaposlenosti u kratkom roku. Međutim, Avdagic (2015) ne pronalazi značajan utjecaj deregulacije na nezaposlenost u EU i ostalim OECD zemljama od 1980. do 2009., već isključivo stope rasta proizvodnje i uvjeta trgovinske razmjene. Slično, Turrini, Koltay, Pierini, Goffard, i Kiss (2014) analiziraju primarno utjecaj reformi na tržištu rada na nezaposlenost u EU od 2000. do 2011. godine, ali pronalaze značajan učinak tek jaza proizvodnje. Piton i Rycx (2018) pružaju robusne dokaze o utjecaju regulacije na tržištu proizvoda i rada na 24 europske zemlje od 1998. do 2013., no iako koriste jaz BDP-a, inflaciju i produktivnost rada kao kontrolne varijable, njihove rezultate ne objavljuju, već samo napominju kako su statistički značajne. Matuzevičiūtè, Butkus i Karaliūtè (2017) analiziraju odrednice nezaposlenosti u 25 zemalja EU od 2000. do 2012. te pronalaze značajan utjecaj izravnih stranih investicija, ekonomskog rasta, cjenovnog indeksa te državne potrošnje. Porezi, sindikati i tehnološke inovacije se u ovoj analizi nisu pokazale značajnima. Economou i Psarianos (2016) panel analizom testiraju Okunov zakon panel metodom fiksnih efekata za 13 zemalja članica EU od drugog kvartala 1993. do prvog kvartala 2014. te zaključuju kako vrijednost Okunovog koeficijenta metodom prvih diferencija iznosi -0,073 dok je uz jaz verziju $-0,209$.

Nalazi postojeće literature govore u prilog post Keynezijanskoj teoriji, s robusno značajnim učincima makroekonomskih varijabli na nezaposlenost i slabom ili nepostojećom značajnošću institucionalnih varijabli tržišta rada. Blanchard i Wolfers (2000) pritom također ističu kako institucije na tržištu rada ne mogu objasniti opći razvoj nezaposlenosti kroz vrijeme. U ovom radu se analiza u skladu s post Keynezijanskom teorijom fokusira na makroekonomske odrednice kako bi se omogućila, prije svega, analiza perioda od 1995. do 2016. godine, za koji cjeloviti podaci o potencijalnim institucionalnim odrednicama nezaposlenosti u europskim zemljama ne postoje. Postojeći pregled literature upućuje na zaključak kako njihovo neuključivanje neće predstavljati značajnije ograničenje istraživanja.

U radu se koristi panel analiza zbog svojih brojnih metodoloških prednosti u usporedbi s analizom vremenskih serija (Hsiao, 2007). Radom se pritom višestruko doprinosi postojećoj literaturi. Prvo, analiziraju se makroekonomske odrednice u svih 28 zemalja EU. Drugo, promatrani period obuhvaća različita razdoblja u razvoju EU, od uvođenja eura, preko razdoblja prosperiteta i razdoblja kriza, kako bi se detektirale jedinstvene, univerzalne makroekonomske odrednice nezaposlenosti u EU. To je ujedno najduži period analize odrednica nezaposlenosti u EU u odnosu na postojeću literaturu. Treće, uspoređuju se odrednice nezaposlenosti u novim i starim zemljama članicama EU. I konačno, utvrđuje se u kojoj mjeri su odrednice ukupne nezaposlenosti ujedno i odrednice nezaposlenosti mladih. 


\section{Empirijski model}

U radu se analiziraju odrednice nezaposlenosti izabrane na temelju post Keynezijanske teorije (Stockhammer i sur., 2014). Dinamički panel model odrednica nezaposlenosti procijenjen je jednadžbom (1).

$$
u_{i t}=\alpha_{i}+\beta_{1} u_{i t-1}+\beta_{2} g_{i t}+\beta_{3} Y_{i t}+\beta_{4} \pi_{i t}+\beta_{5} r_{i t}+\beta_{6} I_{i t}+\theta_{t}+\varepsilon_{i t}
$$

Pritom $u_{i t}$ predstavlja stopu nezaposlenosti u zemlji $i$ u godini $t, u_{i t-1}$ je stopa nezaposlenosti u prethodnom razdoblju, $g_{i t}$ predstavlja stopu rasta BDP-a, $Y_{i t}$ predstavlja jaz proizvodnje dobiven uz pomoć Hodrick-Prescott (HP) filtera (Hodrick i Prescott, 1997), $\pi_{i t}$ označava inflaciju mjerenu indeksom potrošačkih cijena, $r_{i t}$ je realna dugoročna kamatna stopa, $I_{i t}$ su realne investicije, $\alpha_{i}$ je prostorno specifičan efekt, $\theta_{t}$ je vremenski specifičan efekt, a $\varepsilon_{i t}$ je greška relacije.

Nakon osnovne analize provodi se nekoliko analiza robusnosti inicijalno procijenjenog modela. Prvo se osim osnovnog modela, koji se analizira na uzorku svih zemalja EU, analiza modela iz jednadžbe (1) provodi i na dva poduzorka: na poduzorku starih zemalja članica tj. EU15 i novih zemalja članica EU, odnosno EU13. Drugo, zavisna varijabla stope nezaposlenosti se zamjenjuje varijablom stope nezaposlenosti mladih, dok nezavisne varijable ostaju istovjetne onima u modelu prikazanog jednadžbom (1). U konačnici je dodatno učinjena i analiza Okunovog zakona.

Okunov zakon se empirijski može testirati primjenom dvije metode. Prva je metoda prvih diferencija koja se koristila i u originalnom Okunovom radu iz 1962. godine. Metoda prvih diferencija promatra vezu logaritmirane promjene bruto nacionalnog proizvoda (BNP) i promjene stope nezaposlenosti koju koriste primjerice Economou i Psarianos (2015). U radu se međutim koristi druga metoda, tzv. jaz verzija Okunovog zakona koja predstavlja vezu između jaza stope nezaposlenosti i jaza proizvodnje prikazanu jednadžbom (2). Pri tome jaz nezaposlenosti predstavlja razliku stvarne stope nezaposlenosti, $u_{i t}$, i prirodne stope nezaposlenosti, $u_{i t}^{*}$, dok jaz proizvodnje, $Y_{i t}$, predstavlja razliku stvarne proizvodnje i potencijalne proizvodnje. Metoda jaza se može prikazati pomoću sljedećeg modela s fiksnim efektima:

$$
u_{i t}-u_{i t}^{*}=\alpha_{i}+\beta_{1} Y_{i t}+S_{t}+\varepsilon_{i t}
$$

pri čemu je $\alpha_{i}$ konstanta s prostorno specifičnim efektom, $S_{t}$ je vremenski specifičan efekt, a $\varepsilon_{i t}$ je greška relacije. $u_{i t}^{*}$ označava prirodnu stopu nezaposlenosti dobivenu pomoću (HP) filtera (Perman, Stephan i Tavera, 2015). Prirodna stopa nezaposlenosti je "normalna" stopa nezaposlenosti oko koje fluktuira stvarna stopa nezaposlenosti. Odstupanja stvarne stope nezaposlenosti od prirodne stope nezaposlenosti 
nazivamo cikličkom nezaposlenošću (Krugman i Wells, 2006). Navedeni model s fiksnim efektima odabran je na temelju modificiranog Hausmanovog testa (Hoechle, 2007) čiji rezultati se prikazuju u poglavlju ekonometrijske analize. Provodi se i dodatna analiza robusnosti pomoću regresijskog modela sa slučajnim efektima.

\section{Podaci i metodologija}

\subsection{Podaci}

U radu su korišteni godišnji podaci za vremensko razdoblje od 1995. godine do 2016. godine, dok prostorna komponenta obuhvaća svih 28 zemalja članica Europske unije. Svi podaci korišteni u radu, pripadajući izvori podataka ili metode izračuna prikazani su u Tablici 1.

\section{Tablica 1 .}

\section{DEFINIRANJE VARIJABLI I IZVORI PODATAKA}

\begin{tabular}{|l|l|l|}
\hline \multicolumn{1}{|c|}{ Varijabla (simbol) } & \multicolumn{1}{|c|}{ Opis } & Izvor / metoda izračuna \\
\hline $\begin{array}{l}\text { Stopa nezaposlenosti } \\
\text { (u) }\end{array}$ & $\begin{array}{l}\text { Udio radne snage koji je bez posla, ali je } \\
\text { dostupan za rad i traži posao. }\end{array}$ & World Bank (2017) \\
\hline $\begin{array}{l}\text { Stopa nezaposlenosti } \\
\text { mladih (u_y) }\end{array}$ & $\begin{array}{l}\text { Udio radne snage u dobi od 15 do 24 godine bez } \\
\text { posla, ali dostupni za rad i traže posao. }\end{array}$ & World Bank (2017) \\
\hline $\begin{array}{l}\text { Stopa rasta BDP-a } \\
\text { (g) }\end{array}$ & $\begin{array}{l}\text { Godišnja stopa rasta BDP-a u američkim } \\
\text { dolarima, bazna godina 2010. }\end{array}$ & World Bank (2017) \\
\hline Jaz proizvodnje (Y) & $\begin{array}{l}\text { Predstavlja razliku između stvarnog i } \\
\text { potencijalnog BDP-a. }\end{array}$ & $\begin{array}{l}\text { 100*[log(BDP)-log(BDP*)]; } \\
\text { BDP* izračunan korištenjem } \\
\text { HP filtera }\end{array}$ \\
\hline Inflacija $(\boldsymbol{\pi})$ & $\begin{array}{l}\text { Mjerena godišnjom promjenom indeksa } \\
\text { potrošačkih cijena (CPI). }\end{array}$ & World Bank (2017) \\
\hline $\begin{array}{l}\text { Realna dugoročna } \\
\text { kamatna stopa }(\mathbf{r})\end{array}$ & $\begin{array}{l}\text { Dugoročna kamatna stopa pri kojoj se posuđuje, } \\
\text { prilagođena za inflaciju mjerenu BDP deflatorom. }\end{array}$ & Ameco (2017) \\
\hline Investicije $(\mathbf{I})$ & $\begin{array}{l}\text { Uključuju unaprjeđenje zemljišta, postrojenja, } \\
\text { strojeva; kupnju opreme, izgradnju cesta, } \\
\text { željeznica, škola, ureda, bolnica, komercijalnih i } \\
\text { industrijskih zgrada. Mjerene su u konstantnim } \\
\text { cijenama iz 2010. godine, u američkim dolarima i } \\
\text { izražene kao postotak BDP-a. }\end{array}$ & World Bank (2017) \\
\hline
\end{tabular}




\subsection{Metodologija}

S obzirom na višestruku vremensku i prostornu dimenziju podataka, u radu se koristi panel analiza. Panel podaci omogućuju kontroliranje za neopazivu heterogenost tj. varijable, svojstva prostornih jedinica, koje su nemjerljive ili neopazive (npr. kulturološki faktori), ali i za individualnu heterogenost odnosno varijable koje se mijenjaju tijekom vremena, no ne i prostorno, poput primjerice nacionalnih politika (Torres-Reyna, 2007). Ovom metodologijom se nakon početne analize na uzorku svih 28 zemalja članica EU, analiza provodi odvojeno za stare i nove zemlje članice EU s ciljem provjere homogenosti odrednica, odnosno determiniraju li iste odrednice nezaposlenost u novim i starim zemljama članicama. Stare zemlje članice se odnose na zemlje koje su pristupile EU od 1958. do 1995. godine, dok su nove zemlje članice zemlje koje su pristupile EU nakon 2004. godine.

Prije same analize, u svrhu utvrđivanja stacionarnosti varijabli provedeni su panel testovi jediničnog korijena: Im-Pesaran-Shin (IPS) (Im, Pesaran i Shin, 2003) i Fisher-ov test (Choi, 2001). Navedeni testovi imaju nultu hipotezu koja tvrdi kako svi paneli sadrže jedinični korijen. IPS test jediničnog korijena uzima broj pomaka prema Akaike-ovom informacijskom kriteriju (AIC), dok je za Fisherov test jediničnog korijena za broj pomaka uzeta vrijednost jedan.

Nakon testiranja stacionarnosti, provodi se panel analiza korištenjem stacionarnih varijabli u ranije definiranom empirijskom modelu. Ekonomski problemi kao što su nezaposlenost, sami po sebi imaju dinamičke karakteristike. Zbog postojanja kružnih veza u ekonomiji primjeren model analize je stoga dinamički panel model. Konkretno, koristi se Arellano-Bond procjenitelj generalizirane metode momenata (GMM ili eng. ,generalized method of moments") budući da ona pruža efikasnije procjenitelje od 2SLS (eng. ,two stage least squares“) procjenitelja (Cameron i Trivedi, 2010). Arellano i Bond (1991) koriste prve diferencije kako bi napustili individualne efekte kao instrumente u modelu, već kao instrumente koriste prethodne vrijednosti zavisne varijable (Arellano i Bond, 1991). Klasična metoda momenata koristi uzorak momenata da bi procijenila nepoznate parametre. GMM metoda se razlikuje od klasične metode momenata prema tome što se može nositi s problemom postojanja dva ili više uvjeta momenata koji imaju informacije o nepoznatim parametrima. Također, GMM omogućava procjenu i zaključivanje u sustavu sa $\mathrm{Q}$ jednadžbi i $\mathrm{P}$ nepoznanica, pri čemu je $\mathrm{P} \leq \mathrm{Q}$. Druga prednost GMM je ta što može koristiti druge veličine osim uzorka momenata za procjenu parametara (Sheppard, 2010). Valjanost instrumenata osigurava se zadovoljavanjem uvjeta koreliranosti s nezavisnim varijablama i ortogonalnosti na greške relacije. U kontekstu našeg rada, primjerenost GMM metode proizlazi upravo iz preidentificiranosti procijenjenih modela, odnosno većeg broja instrumenata od broja neza- 
visnih varijabli modela (Tablica 4$){ }^{2}$ Dodatno, kao provjera robusnosti, u analizi se primjenjuje i Blundell-Bond (1998) procjenitelj, također GMM metodom.

U svrhu formalnog testiranja endogenosti, provodi se Sargan test (Sargan, 1958) kako bi se potvrdila valjanost instrumenata. Nulta hipoteza Sargan testa tvrdi kako su svi instrumenti korišteni u modelu opravdani, odnosno kako postoji endogenost u modelu koju je potrebno uvažiti. Pritom se Sargan test temelji na pretpostavci homoskedastičnosti grešaka relacije. Ukoliko postoji problem heteroskedastičnosti u modelu, Sargan test može dovesti do krivih zaključaka (Baum, Schaffer, Stillman, 2003). Eventualno postojanje problema heteroskedastičnosti grešaka relacije utvrđuje se uz pomoć modificiranog Waldovog testa heteroskedastičnosti (Greene, 2000) kojim se testira nulta hipoteza o homoskedastičnosti grešaka relacije. Ukoliko postoji heteroskedastičnost, koristi se heteroskedastično-konzistentni procjenitelj (White, 1980) prilikom procjene dinamičkog panel modela.

Ujedno, budući da navedena metodologija pretpostavlja nepostojanje autokorelacije, u radu se testira autokorelacija Arellano-Bond testom (Cameron i Trivedi, 2010). Nulta hipoteza testa tvrdi kako ne postoji autokorelacija u prvim diferencijama grešaka relacije. Ukoliko su greške serijalno nekorelirane, tada će test pokazati korelaciju prvog reda, ali ne i korelaciju drugog i viših redova.

U konačnici se procjenjuje Okunov zakon, već spomenutom metodom jaza BDP-a kao svojevrsna dodatna provjera robusnosti uloge proizvodnje u nezaposlenosti. Metoda jaza proizvodnje sukladna je originalnom Okunovom pristupu (Oberst i Oelgemöller, 2013). Pritom se koristi statička panel analiza, u skladu s dosadašnjom praksom u postojećoj literaturi (primjerice Economou i Psarianos, 2016; Oberst i Oelgemöller, 2013).

Za početak se provodi dijagnostika modela, testiranjem nultih hipoteza o homoskedastičnosti tzv. modificiranim Waldovim testom (Greene, 2000), nepostojanja autokorelacije (Wooldridge, 2002) i nulte hipoteze o nepostojanju prostorne ovisnosti (Breusch i Pagan, 1980, Friedman, 1937, Pesaran, 2004). Rezultati provedenih testiranja nalaze se u Tablici 2. Budući da je ustanovljen problem prostorne međuovisnosti, izbor između modela s fiksnim i slučajnim efektima utvrđuje se na temelju rezultata modificiranog Hausmanovog testa (Hoechle, 2007) kojim se testira nulta hipoteza o prikladnosti modela slučajnih efekata. Dobiveni rezultati modificiranog Hausmanovog testa prikazani u Tablici 2 ukazuju na prikladnost modela s fiksnim efektima. Ovaj model je i u teorijskom smislu opravdan jer dozvoljava kontroliranje za neopazivu heterogenost i pretpostavlja da postoje individualne karakteristike zemalja koje se ne mijenjaju kroz vrijeme, ali koje su u odre-

2 2SLS metoda bi bila primjerena u slučaju kada je broj instrumenata istovjetan broju nezavisnih varijabli. 
đenoj mjeri korelirane s nezavisnim varijablama. Dodatno, međutim, za provjeru robusnosti procijenjen je i model sa slučajnim efektima. Analiza je provedena na robusnim standardnim pogreškama, tj. pogreškama korigiranim za prostornu ovisnost, heteroskedastičnost i autokorelaciju uz pomoć Driscoll-Kraay procjenitelja (Driscoll i Kraay, 1998) prilagođenima za neuravnoteženi panel prema Hoechle (2007).

Tablica 2.

DIJAGNOSTIKA MODELA PROCJENE OKUNOVOG ZAKONA

\begin{tabular}{|c|c|}
\hline Dijagnostički test & Test statistika \\
\hline Pesaranov test prostorne neovisnosti & $11.145^{* * *}(0.000)$ \\
\hline Modificirani Waldov test & $3459.71^{* * *}(0.000)$ \\
\hline Wooldridgeov test autokorelacije & $18.616^{* * *}(0.000)$ \\
\hline Modificirani Hausman test & $1.4 \mathrm{e}+17^{* * *}(0.000)$ \\
\hline
\end{tabular}

Napomena: $* * *, * * \mathrm{i} *$ odnose se na $1 \%, 5 \%$ i $10 \%$ razine statističke signifikantnosti. U zagradama su izražene p-vrijednosti.

Izvor: Izračun autorica

Prilikom definiranja jaza BDP-a u svrhu procjene Okunovog zakona, za izračun potencijalnog BDP-a (BDP* u Tablici 1) korišten je HP filter koji razdvaja vremensku seriju na trend i cikličku komponentu. Glavna ideja Hodricka i Prescotta (1997) je tehnika kojom bi se uklonio trend iz vremenske serije koju promatramo. Definirali su vrijednost parametra izravnanja za kvartalne podatke koja iznosi 1600 , a prema Ravn-Uhlig pravilu se parametar izravnanja može izračunati za različite frekvencije podataka na sljedeći način:

$$
\lambda=1600 p_{q}^{4}
$$

pri čemu označava broj perioda po kvartalu (Ravn i Uhlig, 2002). Dakle, budući da se radi o godišnjim podacima, parametar izravnanja je izračunan uz prethodnu formulu, te taj parametar iznosi 6,25. Također, Baxter i King (1999) su pokazali da bi vrijednost parametra trebala biti oko 10 za godišnje podatke. 


\section{Empirijska analiza}

\subsection{Deskriptivna analiza podataka}

Prije provođenja ekonometrijske analize grafički se prikazuje kretanje stope nezaposlenosti u EU kroz vremensko razdoblje od 1995. do 2016. godine, te prosječna stopa nezaposlenosti u promatranome razdoblju za svaku zemlju članicu EU. Nakon toga, razmatra se veza pojedinih odrednica i stope nezaposlenosti.

\section{Grafikon 1.}

KRETANJE STOPE NEZAPOSLENOSTI U EU28 (1995. - 2016.)

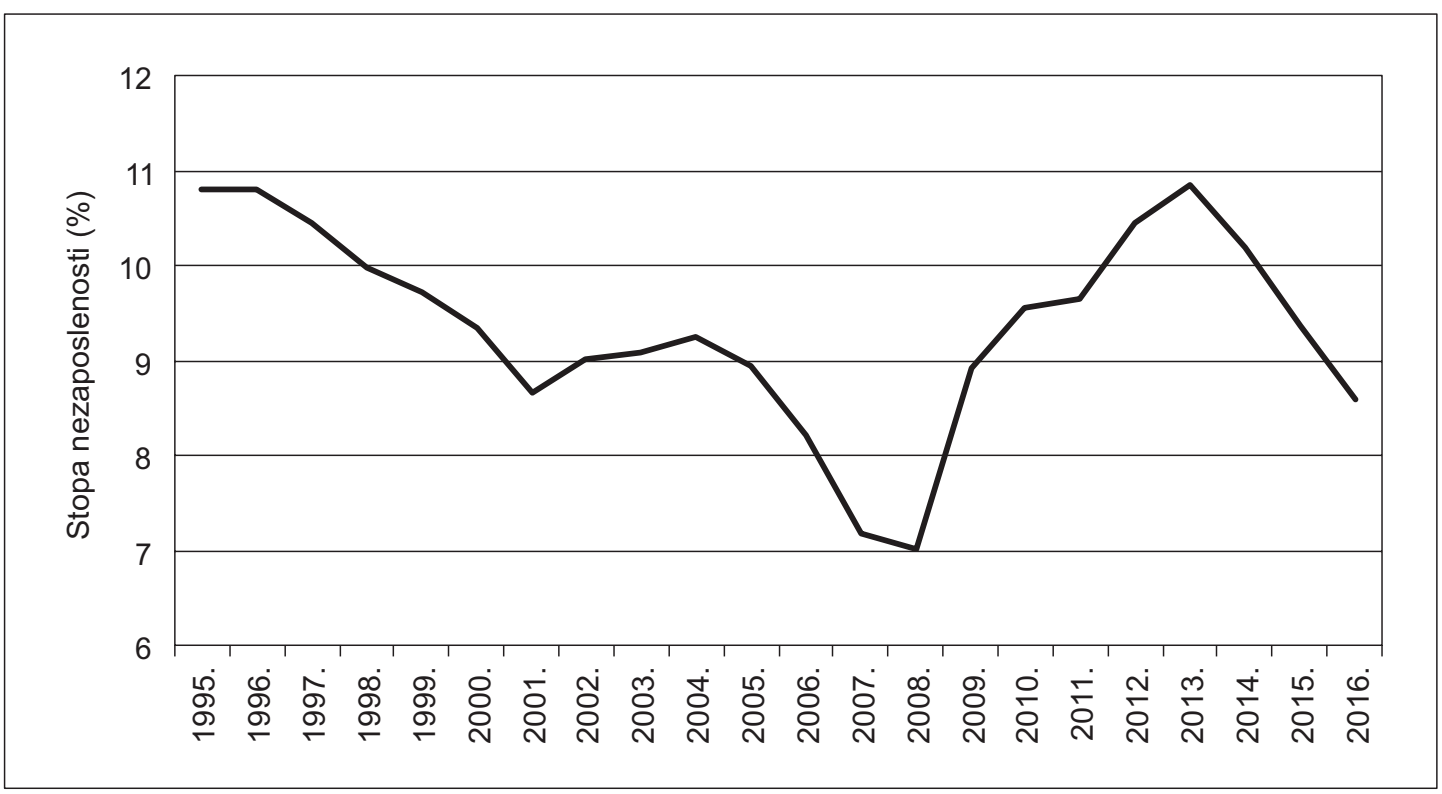

Izvor: Izračun autorica

Na Grafikonu 1 vidljivo je kako je najniža razina nezaposlenosti u promatranome razdoblju dosegnuta 2008. godine nakon koje svjetska gospodarska kriza uzrokuje snažan porast stope nezaposlenosti koja doseže svoj vrhunac 2013. godine. S gospodarskim oporavkom stopa nezaposlenosti se počela smanjivati te u 2016. godini iznosi 8,6\%. Rast zaposlenosti potakle su većinom Njemačka i Španjolska koje su zajedno činile dvije trećine kumulativnog porasta zaposlenosti euro područja od drugog kvartala 2013. godine (ECB, 2016). Međutim, još uvijek 
je prisutna visoka strukturna nezaposlenost i niska stopa rasta potencijalne proizvodnje, što znači da postoji dodatan prostor za daljnja poboljšanja (ECB, 2016).

Grafikon 2.

\section{PROSJEČNA STOPA NEZAPOSLENOSTI OD 1995. DO 2016. U ZEMLJAMA ČLANICAMA EU}

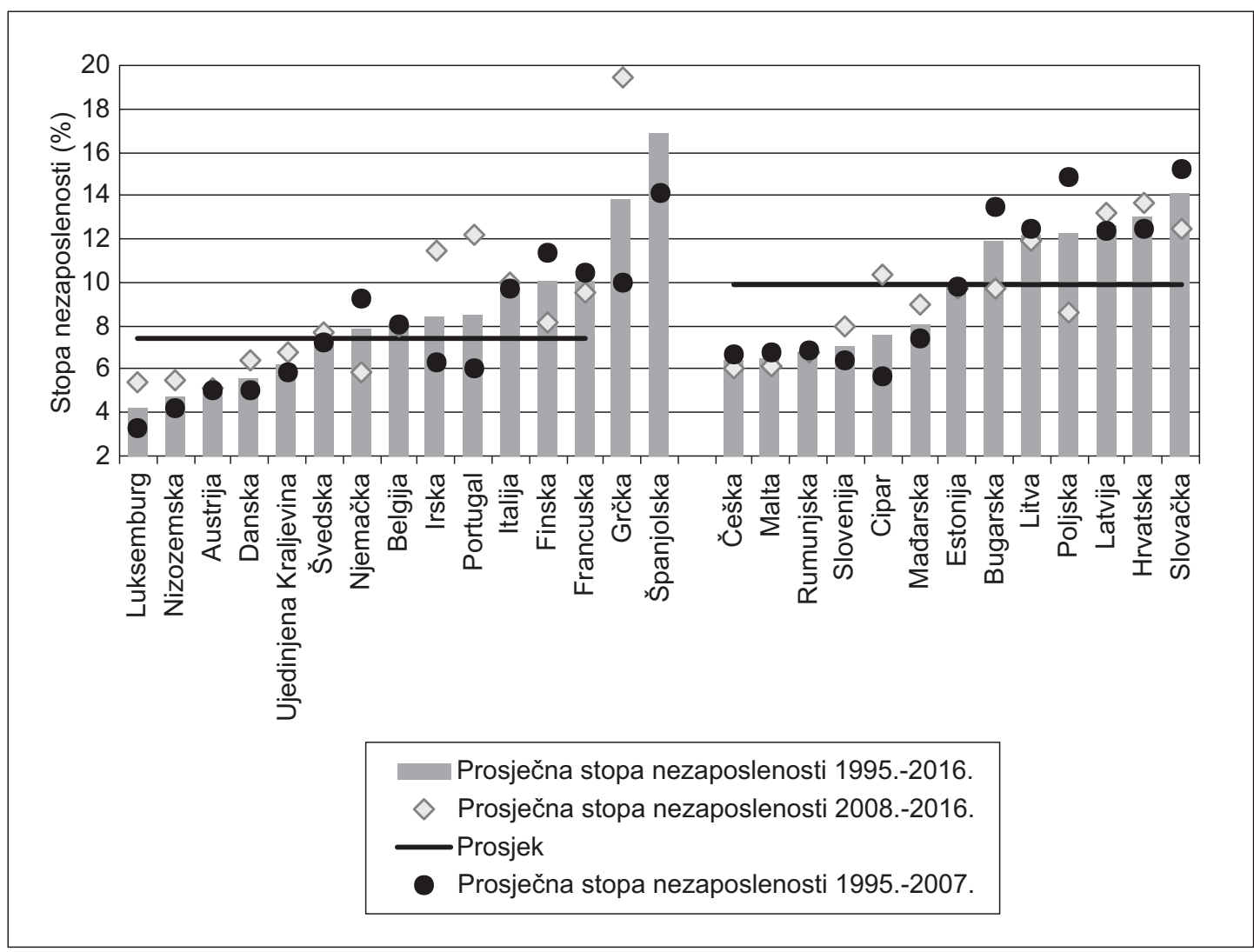

* Napomena: prosjek starih zemalja članica izračunan je bez Grčke i Španjolske Izvor: Izračun autorica

Grafikon 2 prikazuje prosječnu stopu nezaposlenosti od 1995. do 2016. godine za svaku pojedinu zemlju članicu EU. Također, prikazana je prosječna nezaposlenost u razdoblju od 1995. do 2007. i od 2008. do 2016. godine. Zemlje su grupirane u stare i nove zemlje članice. Unutar skupine starih zemalja članica ističu se Grčka i Španjolska po izrazito visokoj prosječnoj stopi nezaposlenosti. Ukoliko se iz izračuna prosječne stope nezaposlenosti u starim zemljama članicama isključe Grčka i Španjolska, vidljiva je u prosjeku viša stopa nezaposlenosti novih zemalja 
članica u odnosu na stare zemlje članice. Ukoliko navedene zemlje uključimo pri izračunu prosječne stope nezaposlenosti starih zemalja članica, smanjuje se razlika između stope nezaposlenosti starih i novih zemalja članica, međutim stopa nezaposlenosti starih zemalja članica je i dalje niža u odnosu na nove zemlje članice.

Grafikon 3.

\section{VEZA STOPE NEZAPOSLENOSTI U VREMENU T I STOPE NEZAPOSLENOSTI U VREMENU T-1 U EU28 ZA RAZDOBLJE OD 1995. DO 2016. GODINE}

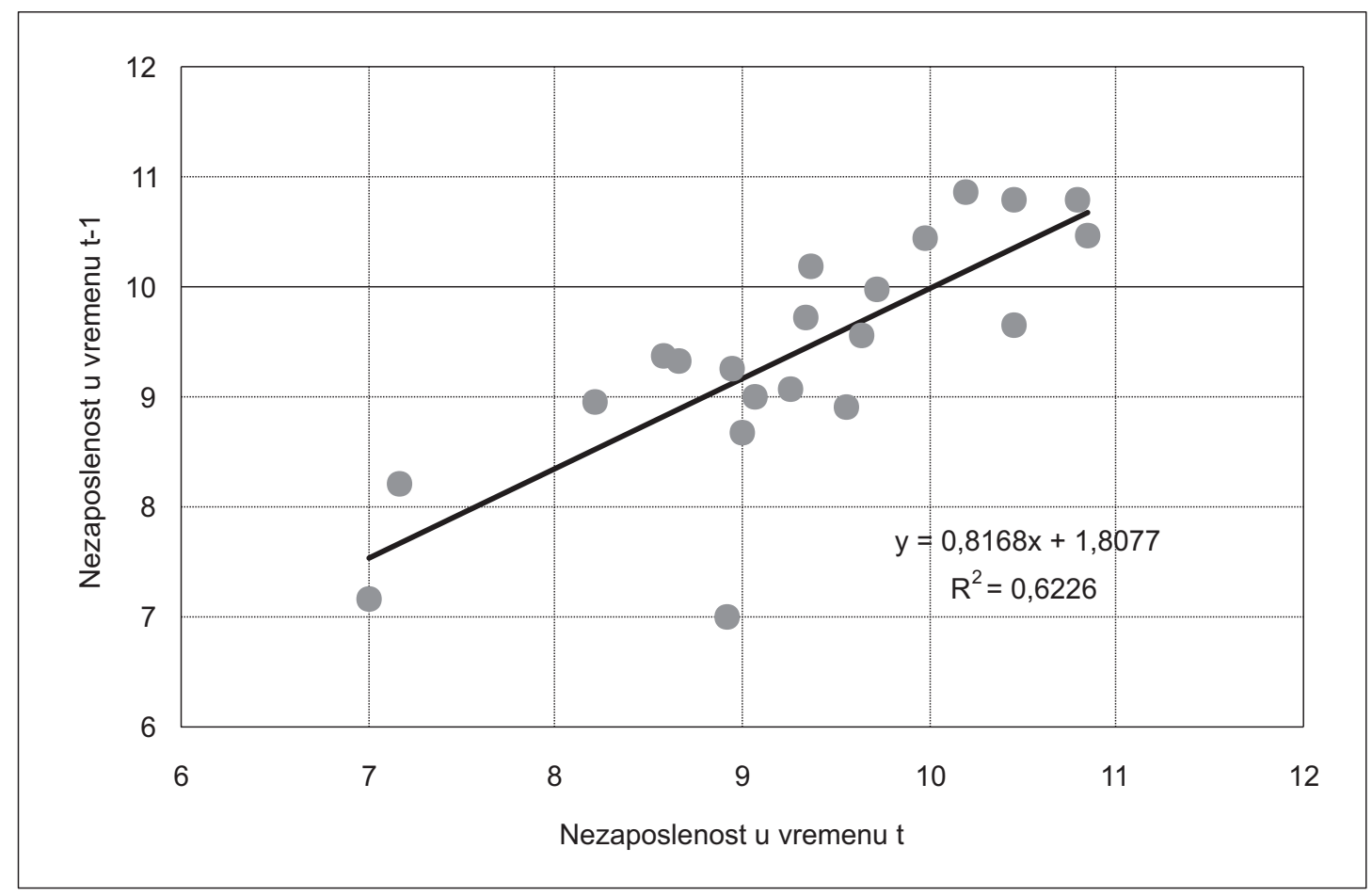

Izvor: Izračun autorica

$\mathrm{Na}$ Grafikonu 3 uočava se pozitivna veza stope nezaposlenosti u vremenu $\mathrm{t}$ i stope nezaposlenosti u vremenu t-1 u EU28 za razdoblje od 1995. do 2016. godine. Budući da dinamički panel model kao nezavisnu varijablu uključuje i zavisnu varijablu s vremenskim pomakom, postojanje endogenosti, prikladnost dinamičkog panel modela i pripadajućeg instrumenta je implicirana ovom jednostavnom deskriptivnom analizom. Također, dobivena pozitivna veza je i očekivana - više stope nezaposlenosti u prethodnom razdoblju uglavnom su praćene visokim stopama nezaposlenosti u narednom razdoblju. 
Grafikon 4 prikazuje negativan odnos između stope nezaposlenosti i stope rasta domaćeg proizvoda za zemlje članice EU od 1995. do 2016. godine. Dakle, očekivana negativna veza između stope rasta BDP-a i stope nezaposlenosti, veza sugerirana Okunovim zakonom, se grafički naslućuje i za EU28. Kao netipična vrijednost ističe se 2009. godina kada stopa rasta BDP-a poprima izrazito negativnu vrijednost uz visoku stopu nezaposlenosti te se navedeno može pripisati učinku krize. Ukoliko se isključi 2009. godina, veza stope rasta BDP-a i stope nezaposlenosti je snažnije negativna u odnosu na vezu promatranih varijabli koja uključuje navedenu godinu.

\section{Grafikon 4.}

VEZA STOPE RASTA BDP-A I STOPE NEZAPOSLENOSTI U EU ZA RAZDOBLJE 1995. - 2016.

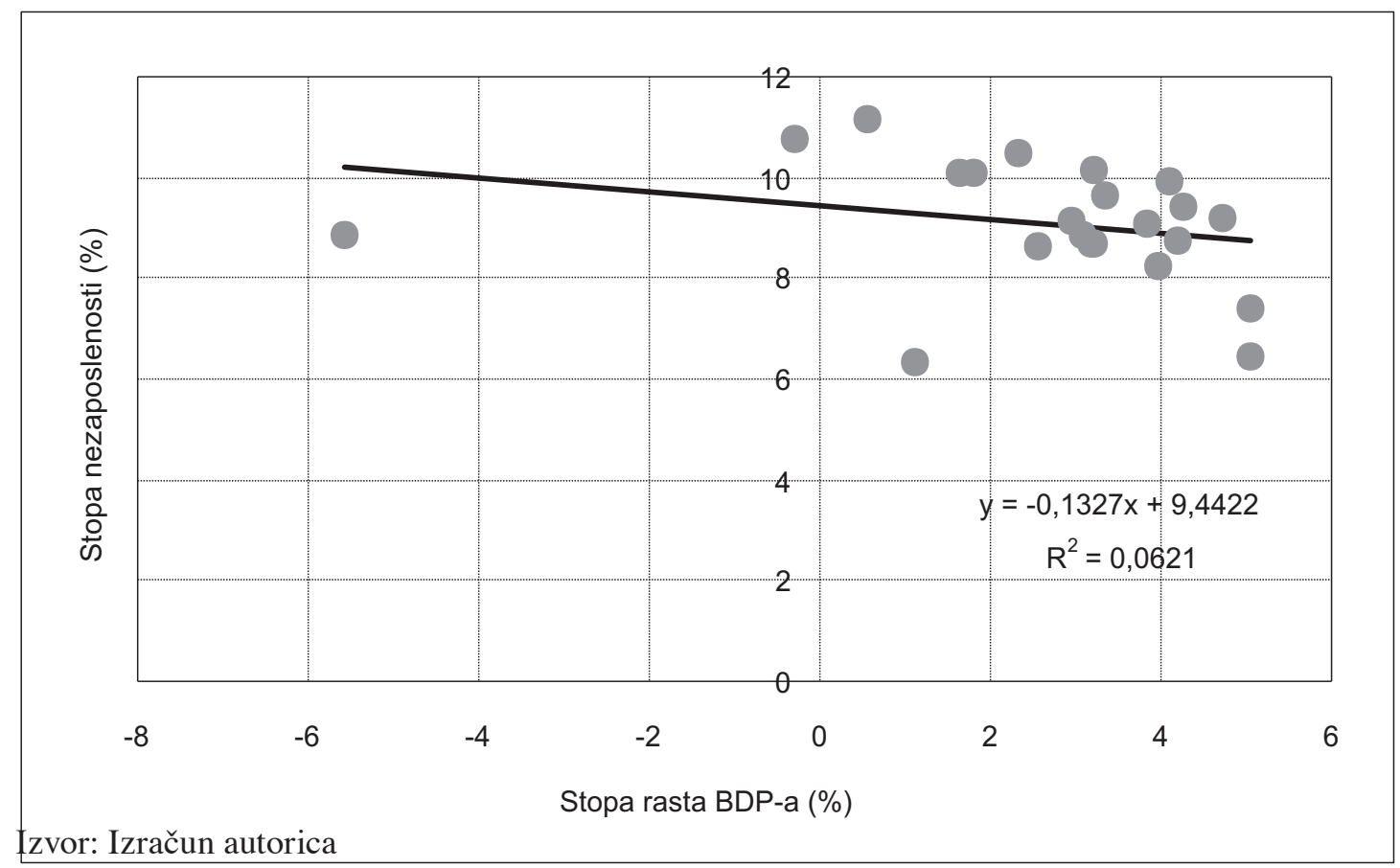

Prema Grafikonu 5 veza inflacije i stope nezaposlenosti gotovo ne postoji. Međutim, s obzirom na isticanje važnosti inflacije kao odrednice nezaposlenosti u prethodno provedenim istraživanjima, navedena varijabla se ipak uključuje u model odrednica nezaposlenosti EU. 


\section{Grafikon 5.}

\section{VEZA STOPE INFLACIJE I STOPE NEZAPOSLENOSTI U EU28}

ZA RAZDOBLJE 1995. - 2016.

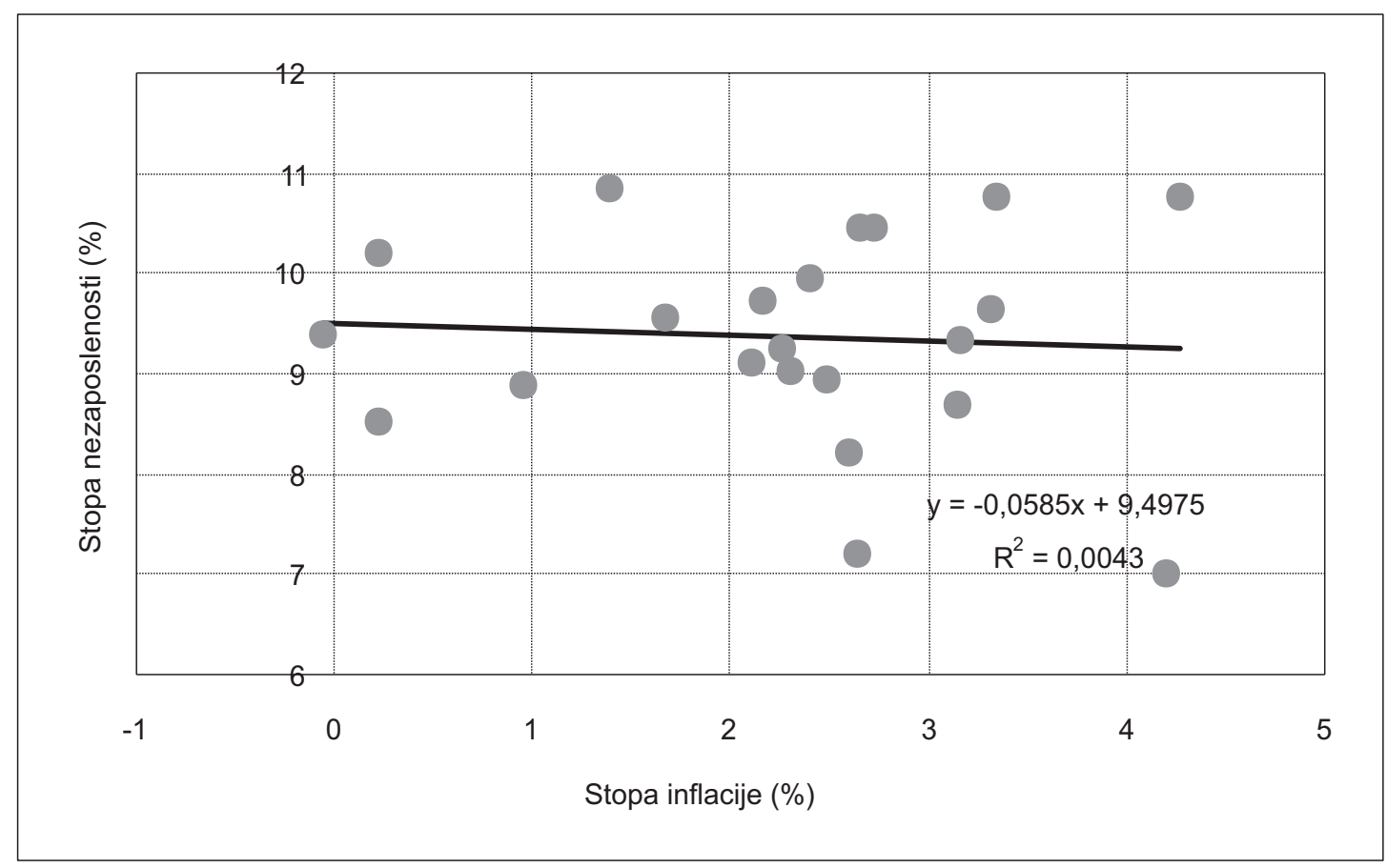

Izvor: Izračun autorica 


\section{Grafikon 6.}

\section{VEZA STOPE NEZAPOSLENOSTI I REALNE KAMATNE STOPE U EU,} PROSJEK 1995. - 2016.

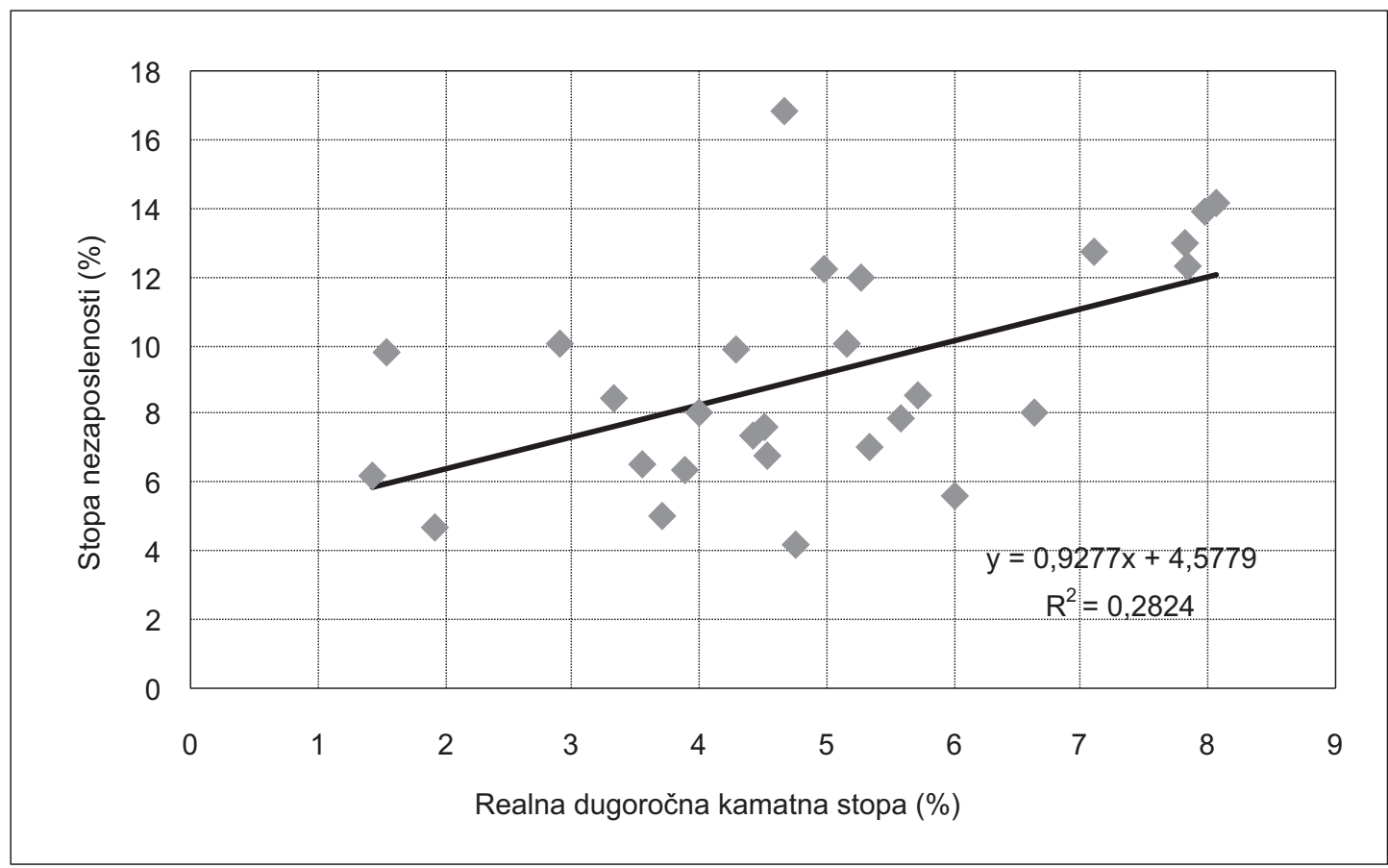

Izvor: Izračun autorica

Prikaz korelacije prosječne stope nezaposlenosti i prosječne realne dugoročne kamatne stope u razdoblju od 1995. do 2016. godine za svih 28 zemalja članica EU dan je na Grafikonu 6. Vidljiva je pozitivna veza između navedenih varijabli, odnosno upravo onakva kakvu predviđa ekonomska teorija. Također, uočava se i teorijski očekivana negativna veza investicija i stope nezaposlenosti u EU na Grafikonu 7. 


\section{Grafikon 7.}

\section{VEZA INVESTICIJA KAO POSTOTKA BDP-A I STOPE NEZAPOSLENOSTI U EU ZA RAZDOBLJE 1995. - 2016.}

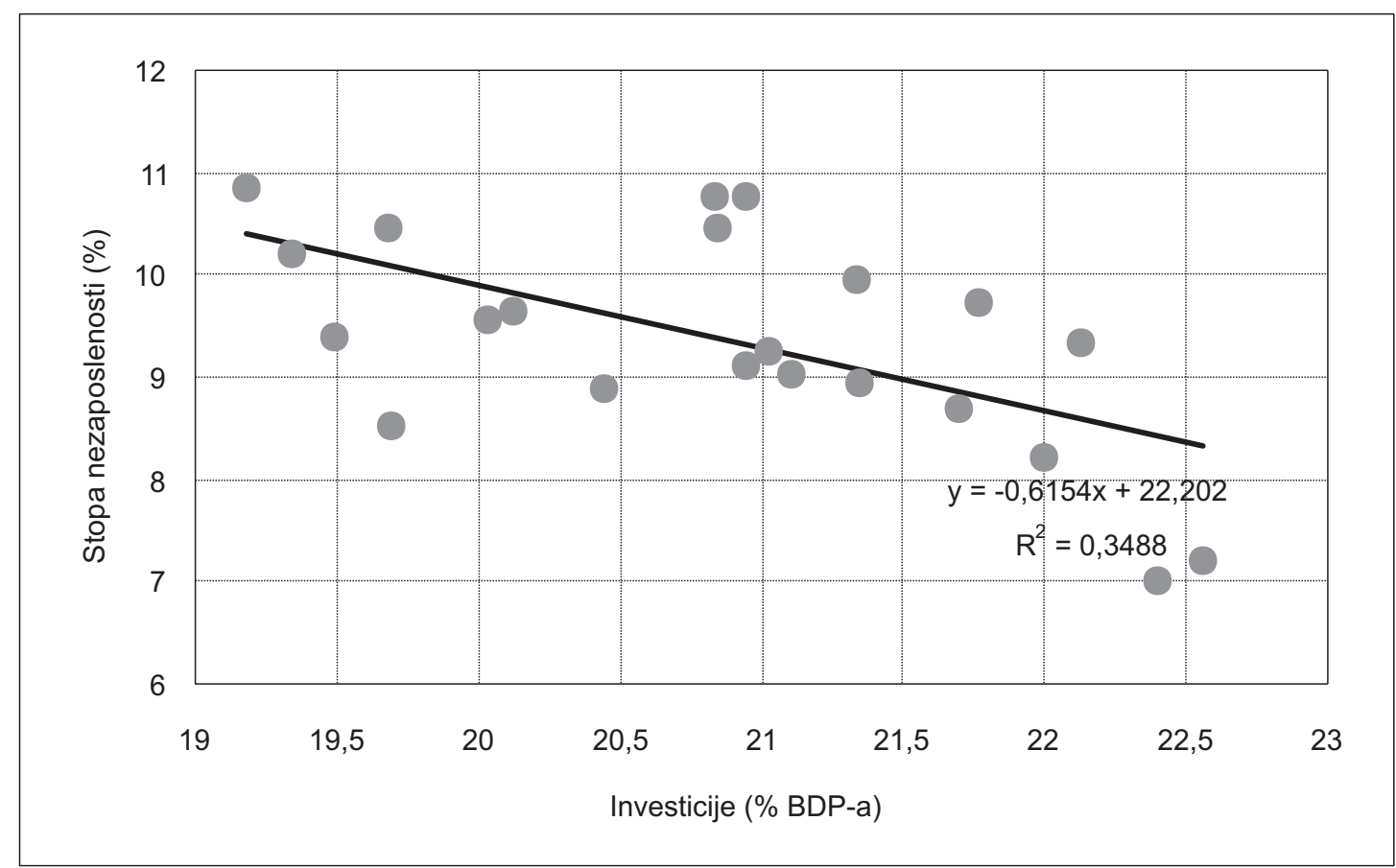

Izvor: Izračun autorica

\subsection{Ekonometrijska analiza}

Kako bi se procijenila važnost navedenih makroekonomskih varijabli pri objašnjavanju nezaposlenosti, provedena je ekonometrijska analiza. Za početak je provedena analiza stacionarnosti varijabli koje se koriste u modelu testovima jediničnih korijena za sve varijable. S obzirom da su panel podaci neuravnoteženi, testovi jediničnog korijena koji se koriste su Fisherov prošireni Dickey-Fuller test (ADF) i Im-Pesaran-Shin (IPS) test jediničnog korijena. Dobiveni rezultati prikazani su Tablicom 3. Prema navedenim testovima jediničnog korijena sve varijable su stacionarne te su kao takve uključene u analizu. 
Tablica 3.

\section{ANALIZA STACIONARNOSTI VARIJABLI}

\begin{tabular}{|c|c|c|c|c|c|c|}
\hline \multirow{2}{*}{ VARIJABLE } & \multicolumn{3}{|c|}{ IPS } & \multicolumn{2}{c|}{ ADF } \\
\cline { 2 - 7 } & $\begin{array}{c}\text { Bez } \\
\text { konstante i } \\
\text { trenda }\end{array}$ & Konstanta & $\begin{array}{c}\text { Konstanta } \\
\text { i trend }\end{array}$ & $\begin{array}{c}\text { Bez } \\
\text { konstante i } \\
\text { trenda }\end{array}$ & Konstanta & $\begin{array}{c}\text { Konstanta } \\
\text { i trend }\end{array}$ \\
\hline $\begin{array}{c}\text { Stopa } \\
\text { nezaposlenosti }\end{array}$ & $-5.426 * * *$ & $-4.174 * * *$ & $-3.283 * * *$ & $-5.248 * * *$ & $-4.557 * * *$ & $-4.134 * * *$ \\
\hline $\begin{array}{c}\text { Stopa } \\
\text { nezaposlenosti } \\
\text { mladih }\end{array}$ & $-3.8764 * *$ & $-3.0995 * * *$ & $-1.3424 *$ & $-3.8629 * * *$ & $-2.9241 * * * *$ & $-1.3489 *$ \\
\hline $\begin{array}{c}\text { Stopa rasta } \\
\text { BDP-a }\end{array}$ & $-8.961 * * *$ & $-7.790 * * *$ & $-5.248 * * *$ & $-7.715 * * *$ & $-7.320 * * *$ & $-4.539 * * *$ \\
\hline Jaz proizvodnje & $-15.073 * * *$ & $-14.746 * * *$ & $-10.890 * * *$ & $-16.422 * * *$ & $-16.044 * * *$ & $-12.014 * * *$ \\
\hline Inflacija & $-9.505 * * *$ & $-14.284 * * *$ & $-16.419 * * *$ & $-6.739 * * *$ & $-9.497 * * *$ & $-11.386 * * *$ \\
\hline $\begin{array}{c}\text { Dugoročna } \\
\text { kamatna stopa }\end{array}$ & $-2.617 * * *$ & $-4.268 * * *$ & $-4.466 * * *$ & $-2.159 * *$ & $-2.359 * * *$ & $-3.361 * * *$ \\
\hline $\begin{array}{c}\text { Investicije } \\
\text { (\%BDP-a) }\end{array}$ & $-1.501 *$ & $-1.595 *$ & $-1.142 * * *$ & $-2.434 * * *$ & $-2.536 * * *$ & -0.952 \\
\hline
\end{tabular}

Napomena: $* * *, * * \mathrm{i} *$ odnose se na $1 \%, 5 \%$ i $10 \%$ razine statističke signifikantnosti

Izvor: Izračun autorica

Procijenjeni panel model odrednica nezaposlenosti (jednadžba 1) prikazan je Tablicom 4. Prvo, procijenjen je model za sve zemlje članice EU Arellano-Bond te potom Blundell-Bond procjeniteljem, a zatim zasebno za nove i stare zemlje članice EU. Robusnost inicijalno procijenjenog modela dodatno je provjerena tako što je zavisna varijabla stopa nezaposlenosti zamijenjena varijablom stope nezaposlenosti mladih. 
Tablica 4.

PANEL MODELI ODREDNICA UKUPNE NEZAPOSLENOSTI U EU28, EU15 I EU13, TE NEZAPOSLENOSTI MLADIH - ARELLANO-BOND I BLUNDELL-BOND GMM PROCJENITELJI

\begin{tabular}{|c|c|c|c|c|c|}
\hline Varijable & $\begin{array}{l}\text { EU28 - Arellano- } \\
\text { Bond }\end{array}$ & $\begin{array}{c}\text { EU28 - Blundell- } \\
\text { Bond }\end{array}$ & $\begin{array}{l}\text { EU15 - Arellano- } \\
\text { Bond }\end{array}$ & $\begin{array}{l}\text { EU13 - Arellano- } \\
\text { Bond }\end{array}$ & $\begin{array}{l}\text { Nezaposlenost } \\
\text { mladih - } \\
\text { Arellano-Bond }\end{array}$ \\
\hline $\mathrm{u}(-1)$ & $0.498 * * *(0.000)$ & $0.737 * * *(0.000)$ & & & \\
\hline $\mathrm{g}$ & $-0.026(0.334)$ & $-0.042(0.176)$ & & & $-0.327 * * *(0.000)$ \\
\hline $\mathrm{Y}$ & $-0.222 * * *(0.002)$ & $-0.258 * * *(0.000)$ & & & $-0.260 *(0.062)$ \\
\hline $\mathrm{I}$ & $-0.169 * *(0.048)$ & $-0.019(0.764)$ & & & $-0.041(0.801)$ \\
\hline $\mathrm{r}$ & $0.166 * * *(0.000)$ & $0.296 * * *(0.000)$ & & & $0.338^{* * *}(0.000)$ \\
\hline$\pi$ & $0.101 * * *(0.004)$ & $0.225^{* * *}(0.001)$ & & & $0.201(0.119)$ \\
\hline $\mathrm{t}$ & $0.010(0.717)$ & $0.105 * * *(0.000)$ & $0.000(0.983)$ & $0.007(0.688)$ & $0.033(0.583)$ \\
\hline $\mathrm{u}_{-} \mathrm{y}(-1)$ & & & & & $0.812 * * *(0.000)$ \\
\hline $\mathrm{u}(-1)$ EU15 & & & $0.653 * * *(0.000)$ & & \\
\hline $\mathrm{g}$ EU15 & & & $-0.091(0.272)$ & & \\
\hline YEU15 & & & $-0.124(0.344)$ & & \\
\hline I EU15 & & & $-0.261 * *(0.028)$ & & \\
\hline rEU15 & & & $0.157 *(0.079)$ & & \\
\hline$\pi \mathrm{EU15}$ & & & $0.079(0.388)$ & & \\
\hline $\mathrm{u}(-1) \mathrm{EU} 13$ & & & & $0.608 * *(0.030)$ & \\
\hline $\mathrm{g}$ EU13 & & & & $-0.018(0.852)$ & \\
\hline YEU13 & & & & $-0.252(0.131)$ & \\
\hline IEU13 & & & & $0.035(0.767)$ & \\
\hline rEU13 & & & & $0.206 * * *(0.000)$ & \\
\hline$\pi \mathrm{EU13}$ & & & & $0.091(0.339)$ & \\
\hline Konstanta & $7.025 * * *(0.002)$ & $0.122(0.943)$ & $3.814 * *(0.043)$ & $0.095(0.934)$ & $3.590(0.492)$ \\
\hline $\mathrm{N}$ & 489 & 517 & 489 & 489 & 489 \\
\hline Sargan test & $21.506(0.368)$ & $23.206(0.984)$ & $11.992(0.886)$ & $7.196(0.988)$ & $24.312(0.185)$ \\
\hline $\begin{array}{l}\text { Arellano- } \\
\text { Bond test }\end{array}$ & & & & & \\
\hline $\begin{array}{l}\text { 1.red } \\
\text { 2.red }\end{array}$ & $\begin{array}{c}-2.4885^{* *}(0.013) \\
-4887(0.6251)\end{array}$ & $\begin{array}{c}-3.0475 * * *(0.002) \\
-1.2043(0.229)\end{array}$ & $\begin{array}{c}-2.3485^{* *}(0.019) \\
-1.1168(0.264)\end{array}$ & $\begin{array}{c}-1.0294 * *(0.033) \\
0.6009(0.548)\end{array}$ & $\begin{array}{c}-2.995 * * *(0.003) \\
1.2366(0.216)\end{array}$ \\
\hline $\begin{array}{c}\text { Modificirani } \\
\text { Wald test }\end{array}$ & $\begin{array}{c}2050.53 * * * \\
(0.000)\end{array}$ & $\begin{array}{c}2050.53^{* * * *} \\
(0.000)\end{array}$ & $\begin{array}{c}5.0 \mathrm{e}+07 * * * \\
(0.000)\end{array}$ & $\begin{array}{c}2.6 \mathrm{e}+09 . * * *) \\
(0.000)\end{array}$ & $\begin{array}{c}2791.30 * * * \\
(0.000)\end{array}$ \\
\hline $\begin{array}{c}\text { Broj } \\
\text { instrumenata } \\
\end{array}$ & 28 & 48 & 27 & 26 & 27 \\
\hline
\end{tabular}

Napomena: $* * *, * * \mathrm{i} *$ odnose se na $1 \%, 5 \%$ i $10 \%$ razine statističke signifikantnosti. U zagradama su izražene p-vrijednosti.

Izvor: Izračun autorica 
Arellano-Bond test autokorelacije pokazao je nepostojanje autokorelacije u niti jednom od procijenjenih modela (Tablica 4). Nadalje, uz intuitivni zaključak primjerenosti dinamičke panel analize uslijed postojanja kružnih veza u ekonomiji, p-vrijednosti Sargan testa upućuju na prihvaćanje nulte hipoteze o validnosti instrumenata u svim analiziranim modelima te se i formalno zaključuje o adekvatnosti provođenja dinamičke panel analize. Proveden je i modificirani Waldov test heteroskedastičnosti, prema kojemu se odbacuje nulta hipoteza o homoskedastičnosti grešaka relacije (Tablica 4) te se stoga u analizi koristi heteroskedastičnokonzistentni procjenitelj (White, 1980).

S obzirom da se radi o dinamičkom panel modelu, zavisna varijabla stopa nezaposlenosti se pojavljuje i kao nezavisna s vremenskim pomakom. Varijabla stopa nezaposlenosti s vremenskim pomakom je statistički značajna u svim modelima (Tablica 4). Moguće je zaključiti kako najveći utjecaj na povećanje stope nezaposlenosti danas ima stopa nezaposlenosti iz prethodnog razdoblja. Time je potvrđen određen stupanj perzistentnosti nezaposlenosti koji je već uočen u postojećoj literaturi (Raguž Krištić, Rogić Dumančić i Arčabić, 2018).

Procijenjeni koeficijent stope rasta BDP-a je očekivanoga negativnog predznaka, odnosno ukoliko se stopa rasta BDP-a poveća, tada se očekuje da će se stopa nezaposlenosti smanjiti. Međutim, varijabla je statistički značajna i to na razini od $1 \%$ samo u dinamičkom modelu nezaposlenosti mladih. S druge strane, procijenjeni koeficijent jaza proizvodnje je također očekivanoga negativnog predznaka te je statistički značajan isključivo na razini EU28, i to u slučaju ukupne nezaposlenosti i nezaposlenosti mladih. U EU15 i EU13, niti stopa rasta proizvodnje niti jaz proizvodnje nisu značajni. Proizvodnja je dakle, očekivano, povezana s nižom stopom nezaposlenosti. Zanimljivo je, međutim, da se proizvodnja niti u jednom obliku nije pokazala značajnom determinantom niti u EU13 niti u EU15 odvojeno. Potrebna je dodatna analiza kojom bi se točno utvrdila pozadina ovakvih rezultata, no vrlo je izgledno kako povećanje proizvodnje u EU15 u značajnoj mjeri smanjuje nezaposlenost u novim zemljama članicama, prvenstveno preko mehanizma migracija.

Koeficijent uz realnu dugoročnu kamatnu stopu ima pozitivan predznak kakav je i pretpostavljen u postojećoj teorijskoj literaturi. Varijabla je značajna uz razinu signifikantnosti $1 \%$ u svim promatranim modelima, sugerirajući kako povoljniji uvjeti kreditiranja mogu u prosjeku smanjiti i ukupnu i nezaposlenost mladih u svim zemljama EU. Međutim, rezultati procjene koeficijenta investicija izraženih kao postotak BDP-a nisu jednako robusni. S očekivanim negativnim predznakom kao statistički značajne pojavljuju se samo u EU28 i EU15 modelima s ArellanoBond procjeniteljem. Prema dobivenim rezultatima, investicije dakle u prosjeku ne pridonose smanjenju ukupne nezaposlenosti u novim zemljama članicama EU, kao ni smanjenju nezaposlenosti mladih. Budući da se utjecaj investicija na nezaposle- 
nost u literaturi nerijetko, osim preko njihovog utjecaja na potražnju i proizvodnju, prati i preko njihovog negativnog učinka na marže poduzeća uslijed veće konkurencije na tržištu, ovakav rezultat daje naslutiti kako su investicije u EU13 koncentriranije u postojeća poduzeća uslijed slabije razvijene kulture poduzetništva.

Posljednja varijabla u modelu je inflacija koja pokazuje značajan pozitivan učinak na stopu ukupne nezaposlenosti, ali samo na razini EU28. Na dezagregiranoj razini, inflacija nema značajan učinak na nezaposlenost, kao niti na nezaposlenost mladih. Time post Keynezijanska teorija nije robusno potvrđena te su potrebne detaljnije analize stvarnog funkcioniranja ovog mehanizma u EU.

U nastavku je provedena dodatna analiza robusnosti procjenom jaz verzije modela Okunovog zakona. Zavisna varijabla predstavlja razliku između stvarne nezaposlenosti i prirodne stope nezaposlenosti, dok je nezavisna varijabla jaz proizvodnje koji je dobiven kao razlika stvarne i potencijalne proizvodnje. Rezultati modificiranog Hausmanovog testa prikazani u Tablici 2 pokazuju prikladnost modela s fiksnim efektima u procjeni Okunovog zakona u EU28. Okunov koeficijent prema izabranom modelu (model Okun_fe) za EU u razdoblju od 1995. do 2016. godine iznosi -0,36, kako je prikazano u Tablici 5. Navedeni koeficijent može se interpretirati na sljedeći način: ukoliko se jaz proizvodnje poveća za jedan postotni bod, jaz nezaposlenosti će se smanjiti za 0,36 postotnih bodova. Robusnost modela Okunovog zakona provjerena je modelom sa slučajnim efektima (model Okun_re) prema kojemu se može zaključiti kako je model robustan. Ovom analizom potvrđeni su raniji zaključci o značajnoj ulozi proizvodnje u smanjivanju nezaposlenosti na razini EU.

Tablica 5.

\section{REZULTATI PROCJENE OKUNOVOG ZAKONA U EU ZA RAZDOBLJE 1995. - 2016.}

\begin{tabular}{|c|c|c|}
\hline Varijable & Okun_fe & Okun_re \\
\hline $\mathrm{Y}$ & $-0.356^{* * *}(0.000)$ & $-0.356^{* * *}(0.000)$ \\
\hline Konstanta & $-0.015(0.644)$ & $-0.015(0.636)$ \\
\hline $\mathrm{N}$ & 616 & 616 \\
\hline $\mathrm{R}^{2}$ & 0.4298 & \\
\hline Prilagođeni $\mathrm{R}^{2}$ & 0.4026 & \\
\hline
\end{tabular}

Napomena: $* * *, * * \mathrm{i} *$ odnose se na $1 \%, 5 \%$ i $10 \%$ razine statističke signifikantnosti. U zagradama su izražene p-vrijednosti. Okun_fe se odnosi na model s fiksnim efektima, a Okun_re na model sa slučajnim efektima.

Izvor: Izračun autorica 


\section{Zaključak}

Cilj ovog rada bio je prikazati makroekonomske odrednice nezaposlenosti te dublje istražiti vezu između nezaposlenosti i proizvodnje koja se definira Okunovim zakonom. U radu su analizirane makroekonomske odrednice nezaposlenosti: stopa rasta bruto domaćeg proizvoda, jaz proizvodnje, inflacija, realna dugoročna kamatna stopa, te realne investicije. Navedene varijable odabrane su na temelju post Keynezijanske ekonomske teorije te rezultata prethodno provedenih istraživanja. Analizirane su sve zemlje članice EU, u vremenskom periodu od 1995. do zaključno 2016. godine. Korištena je dinamička panel analiza odrednica ukupne nezaposlenosti i nezaposlenosti mladih te je provedena dodatna analiza robusnosti testiranjem Okunovog zakona statičkim panel modelom s fiksnim efektima. Ovaj rad predstavlja značajan doprinos postojećoj literaturi s obzirom na sveobuhvatnost provedene analize utemeljene na ekonomskoj teoriji, koja uključuje svih 28 zemalja članica EU kroz do sada najduži period promatranja, ispitivanje homogenosti odrednica unutar EU te analizu odrednica nezaposlenosti mladih.

Rezultati dinamičkog panel modela na razini čitave EU pokazali su da su varijable stopa nezaposlenosti u razdoblju t-1, jaz proizvodnje, investicije, realna dugoročna kamatna stopa i inflacija značajne pri objašnjavanju stope nezaposlenosti, iako zaključak o investicijama nije robustan. Pritom je utvrđeno kako realna dugoročna kamatna stopa, inflacija i nezaposlenost u prethodnom razdoblju povećavaju nezaposlenost, dok ju jaz proizvodnje i investicije smanjuju. Analiza Okunovog zakona rezultirala je Okunovim koeficijentom od -0,36, što znači da je potvrđena i valjanost Okunovog zakona u EU.

Usporedna analiza odrednica nezaposlenosti u starim i novim zemljama članicama EU govori nam o relativnoj homogenosti odrednica nezaposlenosti u dvjema skupinama zemalja, pri čemu jedinu iznimku čine investicije sa svojim značajnim učinkom na nezaposlenost isključivo u starim zemljama članicama, potencijalno ukazujući na relativno nepovoljnu poduzetničku klimu u novim zemljama članicama. Nezaposlenost iz prethodnog razdoblja i realna dugoročna kamatna stopa su značajne odrednice nezaposlenosti u obje skupine zemalja, dok se proizvodnja (bilo u obliku stope rasta proizvodnje ili jaza proizvodnje) i inflacija nisu pokazale statistički značajnim odrednicama u analiziranim poduzorcima.

U okviru analize odrednica nezaposlenosti mladih, rezultati su pokazali određenu dozu usklađenosti s odrednicama ukupne nezaposlenosti (nezaposlenost prethodnog razdoblja, proizvodnja i realna kamatna stopa). Jedinu razliku čini inflacija koja prema nalazima provedene analize ne igra ulogu u smanjivanju velikog problema nezaposlenosti mladih u EU. Investicije se nisu pokazale značajnim faktorom u smanjivanju nezaposlenosti mladih, ali nisu niti robusno značajne u 
analizi ukupne nezaposlenosti u EU te bi im stoga u budućim analizama trebalo posvetiti dodatnu pažnju.

Osnovno ograničenje provedenog istraživanja predstavlja isključivanje institucionalnih varijabli tržišta rada kao potencijalnih odrednica stope nezaposlenosti u EU. Spomenute varijable nisu uključene zbog nedostupnosti podataka o njima u promatranom periodu analize za svih 28 zemalja članica EU. Međutim, s obzirom na nalaze postojeće literature koja uglavnom ne uspijeva potvrditi njihovu značajnu ulogu u kretanju stopa nezaposlenosti, te s obzirom na teorijsku podlogu provedene analize, ovo ne predstavlja značajnije ograničenje istraživanja.

Rezultati ovog istraživanja su značajni za donosioce ekonomskih politika jer sugeriraju potencijalnu efikasnost određenih politika na strani potražnje u smanjenju stope nezaposlenosti u EU, u prvom redu kroz smanjenje dugoročnih realnih kamatnih stopa. Međutim, istraživanje je otvorilo i neka zanimljiva pitanja poput nehomogene uloge investicija u nezaposlenosti starih i novih zemalja članica, kao i nezaposlenosti mladih, čije je pozadinske mehanizme potrebno podrobnije istražiti u nekim budućim istraživanjima.

\section{Literatura}

1. Adascalitei, D. i Morano, C. P. (2015). Labour market reforms since the crisis: Drivers and consequences. International Labour Office Working paper, No. 5, 1-19. Dostupno na http://www.ilo.org/wcmsp5/groups/public/---dgreports/--inst/documents/publication/wcms_414588.pdf

2. Arellano, M. i Bond, S. (1991). Some Tests of Specification for Panel Data: Monte Carlo Evidence and an Application to Employment Equations. Review of Economic Studies, 2(58), 277-297. https://doi.org/10.2307/2297968

3. Avdagic, S. (2015). Does deregulation work? Reassessing the unemployment effects of employment protection. British Journal of Industrial Relations, 53(1), 6-26. https://doi.org/10.1111/bjir.12086

4. Bacarro, L. i Rei, D. (2007). Institutional Determinants of Unemployment in OECD Countries: Does the Deregulatory View Hold Water? International Organization, 61(3), 527-569. https://doi.org/10.1017/S0020818307070221

5. Ball, L., Leigh, D. i Loungani, P. (2013). Okun's law: Fit at 50?. IMF Working Paper, 10, 1-38. https://doi.org/10.5089/9781475551945.001

6. Baum, C. F., Schaffer, M. E. i Stillman, S. (2003). Instrumental variables and GMM: Estimation and testing. The Stata Journal, 3(1), 1-31. Dostupno na https://www.stata.com/meeting/9uk/IVGMM3316.pdf 
7. Baxter, M. i King, R. G. (1999). Measuring business cycles: Approximate band-pass filters for economic time series. The Review of Economics and Statistics, 81(4), 575-593. https://doi.org/10.1162/003465399558454

8. Bierens, H. J. i Broersma, L. (1993). The relation between unemployment and interest rate. Econometric Reviews, 12(2), 217-256. https://doi. org/10.1080/07474939308800262

9. Blanchard, O. i Wolfers, J. (2000). The Role of Shocks and Institutions in the Rise of European Unemployment: the Aggregate Evidence. The Economic Journal, 110(March), C1-C33. https://doi.org/10.1111/1468-0297.00518

10. Blanchard, O. (2005). Makroekonomija. Zagreb: Mate.

11. Blundell, R., Bond, S. (1998). Initial conditions and moment restrictions in dynamic panel data models. Journal of econometrics, 87(1), 115-143. https:// doi.org/10.1016/s0304-4076(98)00009-8

12. Breusch, T. S. i Pagan, A. R. (1980). The Lagrange multiplier test and its applications to model specification in econometrics. The Review of Economic Studies 47(1). 239-253. https://dx.doi.org/10.2307/2297111

13. Cameron, A. C. i Trivedi, P. K. (2010). Microeconometrics Using Stata. Texas: Stata press.

14. Choi, I. (2001). Unit root tests for panel data. Journal of International Money and Finance, 20(2), 249-272. https://doi.org/10.1016/S0261-5606(00)00048-6

15. Driscoll, J. C. i Kraay, A. C. (1998). Consistent covariance matrix estimation with spatially dependent panel data. Review of economics and statistics 80(4). 549-560. https://dx.doi.org/10.1162/003465398557825

16. ECB (2012). Euro area labour markets and the crisis. Occasional Paper Series, No. 138, 69-80. Dostupno na: https://www.ecb.europa.eu/pub/pdf/ scpops/ecbocp138.pdf?e31046a7c702c8fe89180e3b3e4bdb1b

17. ECB (2016). The employment-GDP relationship since the crisis. ECB Economic Bulletin, 6(2016), 53-71. Dostupno na https://www.ecb.europa.eu/ pub/pdf/other/eb201606_article01.en.pdf

18. Economou, P. i Psarianos, I. N. (2016). Revisiting Okun's Law in European Union countries. Journal of Economic Studies, 43(2), 275-287. https://doi. org/10.1108/JES-05-2013-0063

19. European Commission, Economic and Financial Affairs (2017). AMECO baza podataka. Dostupno na http://ec.europa.eu/economy_finance/ameco/ user/serie/ResultSerie.cfm

20. Friedman, M. (1937). The use of ranks to avoid the assumption of normality implicit in the analysis of variance. Journal of the American Statistical Association 32(200). 675-701. https://dx.doi.org/10.1080/01621459.1937.10503522 
21. Greene, W. (2000). Econometric Analysis. New York: Prentice-Hall.

22. Hodrick, R. i Prescott, E. C. (1997). Postwar U.S. Business Cycles: An Empirical Investigation. Journal of Money, Credit, and Banking, 29(1), 1-16. https://doi.org/10.2307/2953682

23. Hoechle, D. (2007). Robust standard errors for panel regressions with crosssectional dependence. Stata Journal, 7(3), 281-312. Dostupno na http://fmwww.bc.edu/repec/bocode/x/xtscc_paper.pdf

24. Hsiao, C. (2007). Panel data analysis - advantages and challenges. Test, 16(1), 1-22. https://doi.org/10.1007/s11749-007-0046-X

25. Im, K. S., Pesaran, M. H. i Shin, Y. (2003). Testing for unit roots in heterogeneous panels. Journal of Econometrics, 115(1), 53-74. https://doi.org/10.1016/ S0304-4076(03)00092-7

26. Karfakis, C., Katrakilidis, C. i Tsanana, E. (2014). Does output predict unemployment? A look at Okun's law in Greece. International Labour Review, 153(3), 421-433. https://doi.org/10.1111/j.1564-913X.2014.00018.x

27. Kljaić, A. (2001). Istraživanje problema nezaposlenosti u Hrvatskoj s mogućim prijedlogom rješenja. Ekonomski pregled, 52(1-2), 125-154. Dostupno na https://hrcak.srce.hr/file/45021

28. Krugman, P. i Wells, R. (2006). Macroeconomics. New York: Worth Publishers.

29. Krugman, P. (2012). Revenge of the Optimum Currency Area. NBER Macroeconomics Annual, 27(2012), 439-448. https://doi.org/10.1086/669188

30. Li, J. (2006). Testing Granger Causality in the presence of threshold effects. International Journal of Forecasting, 22(2006), 771-780. https://doi. org/10.1016/j.ijforecast.2006.01.003

31. Matuzevičiūtè, K., Butkus, M., i Karaliūtè, A. (2017). Do technological innovations affect unemployment? Some empirical evidences from European countries. Economies, 5(4), 1-19. https://doi.org/10.3390/economies5040048

32. Obadić, A. (2006). Influence of regional mismatch on the employment process in selected transition countries. Ekonomski pregled, 57(1-2), 3-30. Dostupno na https://pdfs.semanticscholar.org/d1db/6faalfb4f03b4bcad9df1a a19cf3fbele609.pdf

33. Oberst, C. A. i Oelgemöller, J. (2013). Economic Growth and Regional Labor Market Development in German Regions: Okun's Law in a Spatial Context. FCN Working Paper, No. 5/201, 1-33. Dostupno na http://ssrn.com/ abstract $=2240260$

34. OECD (2017). Glossary of statistical terms. Dostupno na https://stats.oecd. org/glossary/detail.asp?ID=2094 
M. LOGARUŠIĆ, I. RAGUŽ KRIŠTIĆ: Odrednice nezaposlenosti u Europskoj Uniji EKONOMSKI PREGLED, 70 (4) 575-602 (2019)

35. Okun, A. M. (1962). Potential GNP: Its Measurement and Significance. Reprinted as Cowles Foundation Paper, 190, 1-7. Dostupno na https://milescorak.files.wordpress.com/2016/01/okun-potential-gnp-its-measurementand-significance-p0190.pdf

36. Perman, R., Stephan, G. i Tavera, C. (2015). Okun's Law - A Meta Analysis. The Manchester School, 83(1), 101-126. https://doi.org/10.1111/manc.12057

37. Pesaran, M. H. (2004). General diagnostic tests for cross section dependence in panels. Cambridge Working Papers in Economics, No. 0435, 1-41. Dostupno na https://www.repository.cam.ac.uk/bitstream/handle/1810/446/ cwpe0435.pdf?sequence $=1 \&$ isAllowed $=\mathrm{y}$

38. Piton, C., i Rycx, F. (2018). The Unemployment Impact of Product and Labour Market Regulation: Evidence from European Countries. Working Papers CEB, 18, 2-33. Dostupno na http://ftp.iza.org/dp11582.pdf

39. Quade, F. F. S. (2003). An Empirical Analysis of the Relationship Between GDP and Unemployment. Humanomics, 19(3), 1-6. https://doi.org/10.1108/eb018884

40. Raguž Krištić, I., Rogić Dumančić, L., i Arčabić, V. (2018). Persistence and stochastic convergence of euro area unemployment rates. Economic Modelling, 2018, 1-7. https://doi.org/10.1016/j.econmod.2018.07.032

41. Ravn, M. O. i Uhlig, H. (2002). Notes on adjusting the Hodrick-Prescott filter for the frequency of observations. The Review of Economics and Statistics, 84(2), 371-380. https://doi.org/10.1162/003465302317411604

42. Sargan, J. (1958). The estimation of economic relationships using instrumental variables. Econometrica, 26(3), 393-415. https://doi.org/10.2307/1907619

43. Sheppard, K. (2010). Financial Econometrics Notes. Oxford: University of Oxford.

44. Stockhammer, E., Guschanski, A. i Köhler, K. (2014). Unemployment, capital accumulation and labour market institutions in the Great Recession. European Journal of Economics and Economic Policies: Intervention, 11(2), 182-194. https://doi.org/10.4337/ejeep.2014.02.05

45. Tercek, D. i Simmons W. (2014). Determinants of European and United States Unemployment. Senior Honors Projects, Paper 33, 1-46. Dostupno na https://collected.jcu.edu/cgi/viewcontent.cgi?referer=https://www.google.hr/ \&httpsredir $=1 \&$ article $=1033 \&$ context=honorspapers

46. The World Bank (2017). World Development Indicators (WDI). Dostupno na http://databank.worldbank.org/data/reports.aspx?source=world-developmentindicators

47. Torres-Reyna, O. (2007). Panel Data Analysis Fixed and Random Effects using Stata. Dostupno na https://www.princeton.edu/ otorres/Panel101.pdf 
48. Turrini, A., Koltay, G., Pierini, F., Goffard, C. i Kiss, A. (2014). A decade of labour market reforms in the EU: Insights from the LABREF database. IZA Policy Paper, No. 88, 1-43. Dostupno na http://ec.europa.eu/economy_finance/publications/

49. White, H. (1980). A Heteroskedasticity-Consistent Covariance Matrix Estimator and a Direct Test for Heteroskedasticity. Econometrica, 48(4), 817838. https://doi.org/10.2307/1912934

50. Wooldridge, J. M. (2002). Econometric Analysis of Cross Section and Panel Data. Cambridge, MA:MIT Press.

\title{
DETERMINANTS OF UNEMPLOYMENT IN THE EUROPEAN UNION
}

\author{
Summary
}

Unemployment as an important economic issue draws the attention of numerous researchers, especially since the global financial crisis which caused high and permanent unemployment rates in the European Union (EU). The main goal of this paper is to identify significant macroeconomic determinants of unemployment in the EU. For this purpose, a dynamic panel analysis was conducted for all EU member countries in the period from 1995 to 2016. The comprehensiveness of the conducted analysis based on the economic theory, which includes all $28 \mathrm{EU}$ member states for the longest period of observation so far, investigation of the homogeneity of determinants on the EU level, and the analysis of the youth unemployment determinants, is how this paper contributes to the existing literature. This analysis confirmed the significance of output gap, investment, real long-term interest rates, inflation, and unemployment in the previous period as the determinants of unemployment in the entire EU, with only real interest rates and previous unemployment robust in all of the models. Unemployment rates in the old and new member states proved relatively homogeneous. The growth rate of production has a significant negative impact only on youth unemployment. The relationship between unemployment gap and output gap has been additionally researched by a static panel analysis and it is concluded that Okun's law in EU is valid, i.e. that there is a negative link between the unemployment gap and the output gap.

Key words: unemployment, Okun's law, dynamic panel 